\title{
Studia anatomiczne jako temat i wyzwanie w sztuce. Historyczny zarys ilustracji anatomicznych i współczesne nawiązania
}

\author{
Beata BigAJ-ZwoneK
}

\begin{abstract}
Streszczenie
Współpraca naukowców i artystów przy realizacji projektów przybliżających anatomię człowieka rozwijała się wraz z dostępnością do głębszych bezpośrednich obserwacji, np. podczas autopsji. Z czasem wzrastało zapotrzebowanie na okazanie ciała: szersza wiedza interesowała medyków, ale i artystów, później także widzów niezwiązanych zawodowo z problematyką medyczną. $\mathrm{W}$ artykule przybliżono historię rozwoju studiów anatomicznych w kontekście ilustracji do podręczników i innych obiektów wizualizujących budowę człowieka. Przedstawiono także przykłady współczesnych nawiązań do tradycji ilustracji anatomicznych w sztuce. Przybliżono przykłady dzieł bazujących na charakterystycznych cechach atlasowych egzemplifikacji, ale odwołujące się do dyskursów społecznych i kondycji człowieka.
\end{abstract}

Słowa kluczowe: ciało, ilustracja anatomiczna, sekcje zwtok, sztuka wspótczesna

Beata BIGAJ-ZwONEK doktor habilitowany, profesor Akademii Ignatianum w Krakowie. Ukończyła Wydział Grafiki ASP w Krakowie. Jej zainteresowania naukowe obejmują wiedzę o kulturze i sztuce, w tym szczególnie problematykę ekspresji w sztuce, procesu twórczego, sztuki społecznej i zaangażowanej. W pracy twórczej zajmuje ją postawa i natura człowieka, swoje obrazy prezentowała na wystawach indywidualnych i zbiorowych.

E-MAIL: beata.bigaj@ignatianum.edu.pl 
Ilustrowanie podręczników anatomii było naturalnym sposobem wizualizacji badań nad ciałem, a doskonałość plansz rosła wraz z rozwojem wiedzy o człowieku. Początkowe rysunki medyków zastępowały w atlasach prace profesjonalnych artystów, którzy poszerzali umiejętności uczestnicząc w sekcjach zwłok, przeprowadzanych częściej od nowożytności. Specyficzną odmianą studiów anatomicznych stały się rysunki metaforyczne, w których martwi bohaterowie przybliżają elementy swojego ciała, w pozach zaczerpniętych z tekstów literackich lub zainspirowanych dziełami sztuki. Uroda, alegoryczność i medyczny kontekst nowożytnych plansz inspirowały artystów i uczonych także w kolejnych wiekach. Z czasem rozwój technologiczny w nauce pozwolił na skupienie się na drobniejszych częściach ciała, a pojawienie się nowych technik wizualizacji (np. fotografii) wpłynęło na charakter obiektów i ilustracji anatomicznych. Jednak wypracowane przez wieki wzory są wciąż interesujące dla sztuki. Formy odniesień do obiektów anatomicznych są w niej różne i zależą od idei dzieła i metody wypowiedzi artystycznej.

W drugiej połowie XIX wieku i później powstają w sztuce obrazy-kadry ludzkiego ciała. Wśród nich szeroko znane jest Pochodzenie świata Gustawa Courbeta (1866), jednak można wymienić również Studium pupy (1884) Feliksa Vallotona czy studia-akty Lovisa Corintha (jak Leżąca naga kobieta, 1907). Dzieła pokazujące ciało, jego fragmenty, czasem dość intymne, w skali 1:1, mają wówczas swoją świeżą odsłonę wyraźnie zainspirowaną nowymi fotograficznymi rozwiązaniami kompozycyjnymi w zakresie kadru. Ich wspólną cechą jest czerpanie z tradycji studiów-szkiców, które przez wieki służyły artystom do poszerzania warsztatu oraz udowadniania klientom, jakimi umiejętnościami dysponują. Wiążą się również z odwiecznym pragnieniem artystów, by zgłębiać piękno ludzkiego ciała. Z ciekawością jego anatomicznej budowy oraz relacji, które składają się na jego funkcje.

Wspomniane obrazy czerpią z wiedzy o budowie ciała rozwijającej się dynamiczniej od nowożytności. W wiekach wcześniejszych, w długich okresach, pogłębianie anatomii w sztuce bywało trudne, niepotrzebne lub niewskazane. Na przeszkodzie stały naciski na skupienie się na przesłaniach duchowych, niezmysłowych, oraz obawy czy praktykom medyków powinni przyglądać się artyści. Jednak z wejściem w nowożytność twórcy coraz częściej łączyli siły z badaczami przy projektach dotyczących anatomii, także na etapie jej odkrywania i opracowywania.

Współdziałanie medyków i artystów umożliwiło miedzy innymi upowszechnienie w medycynie badań nad ciałem poprzez sekcje ludzkich zwłok, 
które rozwinęły się stosunkowo późno. Choć jedno z najstarszych opracowań zaznaczających istotę ludzkich sekcji, Susruta Samhita, może pochodzić z już z X wieku p.n.e., to we wczesnym okresie jest to przypadek wyjątkowy. Badania lekarza i chirurga Samhity prawdopodobnie były prowadzone w sposób szczególny, by nie naruszać hinduskiego prawa mówiącego o świętości ciała po śmierci (Loukas i in. 2010). Często przywoływanym wyjaśnieniem braku szerszych opracowań związanych $\mathrm{z}$ otwieraniem zwłok jest tabu kulturowe. „W starożytnym Egipcie pomimo wielowiekowego zwyczaju balsamowania zwłok anatomia nie wyszła poza dociekania spekulatywne. Krajanie zwłok uchodziło za ich profanację" (Bochenek 1953, 7). Interpretacje konfucjańskiej koncepcji posłuszeństwa związanej z ciałem składającym się z części matki i ojca, o które należy szczególnie dbać, przyczyniły się do obaw przed autopsją w starożytnych Chinach (Zhaojiang 1995, 245). Stosunek do zmarłego ciała w różnych kręgach kulturowych i religiach utrwalony został w rytuałach, które zaznaczają wagę otwierania ciała i traktowania jego organów. W starożytnym Egipcie z uważnością traktowano serce - Ib, które było ośrodkiem rozumu i „bramą wejściową dla bóstwa” (Morenz 1972, 74). W procesie mumifikacji pozostawiano je na miejscu, by mogło towarzyszyć zmarłemu w zaświatach, podczas gdy innych organów się pozbywano. Duchowe znaczenie części ciała wyrażało się w rytuałach pochówku, ale także w filozofii dotykającej anatomii, gdzie ciało człowieka dzielono na strefy mieszczące duszę i odpowiadające za funkcje życiowe, np. u Platona i Arystotelesa (Cunningham 2016, 10-22). Ryszard Grylewski zwraca uwagę, że ograniczenia i nakazy kulturowe nie tłumaczą braku szerokich badań anatomicznych związanych z sekcjami zwłok zwierzęcych, i zaznacza, że przyczyn należy szukać także „w samej istocie pojmowania i tłumaczenia otaczającej człowieka rzeczywistości oraz w języku jej opisu” (Grylewski 2016, 53-54). Porządki naturalny i boski przez wieki wystarczająco tłumaczyły warunki zdrowia człowieka.

Pomyślne okoliczności do rozwoju badań sekcyjnych prowadzonych z zamiarem poznania budowy ciała pojawiły się dopiero w starożytnej Grecji. Przedmiotem bezpośrednich obserwacji były jednak ciała zwierzęce, na ich podstawie wnioskowano o budowie ciała ludzkiego. $Z$ zachowanych źródeł wiemy, że w III wieku p.n.e. prowadzono sekcje ludzkich zwłok w Aleksandrii, później zaniechano autopsji, a brak praktyki sankcjonowano również prawem. Istotny wkład w wiedzę o budowie ludzkiego ciała wniósł rzymski lekarz greckiego pochodzenia Claudius Galenus (Galen). Swoje odkrycia, do 
których przez kolejne wieki odnosili się medycy Galen opracował prawdopodobnie na podstawie sekcji zwierząt. Średniowiecze nie sprzyjało rozwojowi nauk przyrodniczych, greckimi opracowaniami anatomicznymi zajmowano się częściej w krajach arabskich. Dowodem wzrostu zainteresowania się anatomią w późniejszych wiekach są tłumaczenia tekstów arabskich na łacinę: w XI wieku dokonuje ich Konstantyn Afrykańczyk (przypisuje się mu np. Isagoge, wprowadzenie do dzieła Galena), około 1185 roku Galena przekłada Burgundio z Pizy (np. De sectis), a w 1317 roku Niccolò da Reggio De usu partium corporis humani. Informacja o oficjalnych badaniach na ludzkich zwłokach służących rozwojowi wiedzy o ciele pochodzi dopiero z początku XIV wieku. W 1315 roku na Uniwersytecie w Bolonii Mondino de Liuzzi dokonał sekcji dwóch kobiet, o czym wspomina w traktacie Anathomia Mundini (de Liuzzi, 1316). Rafael Mandressi $(2011,285)$ zauważa, że nie jest jasne, co stało na przeszkodzie rozwijania badań anatomicznych na podstawie sekcji ludzkich zwłok przez tak długi czas. Pytanie, czy w świecie chrześcijańskim zastój wynikał z ograniczeń Kościoła nie znajduje klarownej odpowiedzi ${ }^{1}$. „Mamy prawo sądzić, że różnym czasom odpowiadają różne oczywistości i że jeśli przez tyle wieków nie praktykowano sekcji zwłok, to dlatego, iż nie uważano ich za konieczne" (Mandressi 2011, 287). Niewątpliwie jednak tak w kulturze chrześcijańskiej, jak i w kulturach innych wielkich religii istniały trudności w godzeniu autopsji i idei szacunku dla martwego ciała (zob. badania pośmiertne w islamie: Rispler-Chaim i Vardit 1993).

Przed nowożytnością opracowaniom medycznym towarzyszyły dość ubogie w warstwie plastycznej, acz bogato opisane rysunki, tworzone zresztą przez samych badaczy. W świetle zagadnienia anatomii ilustrowanych znaczenie ma publikacja, której autorem jest Guido da Vigevano, włoski lekarz i wynalazca, osobisty medyk królowej Joanny Burgundzkiej. Vigevano swój traktat z roku 1345 Anothomia de signada per figuras zilustrował 24 rysunkami ciał i zabiegów medycznych ${ }^{2}$. Jednym z prekursorów „profesjonalnie” ilustrowanych anatomii był Jacopo Berengario da Carpi, który w latach 20.

1 Co prawda dekret z 1299 roku Detestande feritatis wydany przez Bonifacego VIII sprzeciwiał się „okropnemu zwyczajowi” rozczłonkowywania zwłok, a Henri de Mondeville wspomina, że potrzeba „specjalnego zezwolenia Kościoła rzymskiego”, aby móc wyjmować wnętrzności (w tym przypadku jednak sprawa dotyczyła balsamowania, a nie sekcji anatomicznej), jednak zarazem Guy de Chauliac stwierdza w Wielkiej chirurgii (1363), że zdobycie doświadczenia na zwłokach jest konieczne (Mandressi, 285).

2 Autor zaznaczał, że nieczęsto ma okazję robić sekcję, gdyż ciąży na niej kościelny zakaz, „toteż w celu zaradzenia brakowi bezpośredniej styczności z martwym ciałem postanowił sporządzić ilustracje, aby objaśnić anatomię - on, który tyle razy robił to na ludzkich ciałach" (Mandressi, 285). 
XVI wieku wydał trzy prace zilustrowane drzeworytami (np. Isagogae breves perlucide ac uberrime in anatomiam humani corporis a communi Medicorum Academia usitatam, Bolonia, z 1523 roku), z których niektóre przypisuje się malarzowi i rzeźbiarzowi włoskiego manieryzmu Amico Aspertiniemu. Uważa się, że w swym projekcie Berengario inspirował się rysunkami anatomicznymi Leonarda da Vinci. W grafiki włączone do traktatu wprowadzono wątki narracyjne, które później wpłynęły na dzieło kolejnego znanego anatoma, Andreasa Vesaliusa (Wesaliusza) (Christies 2007).

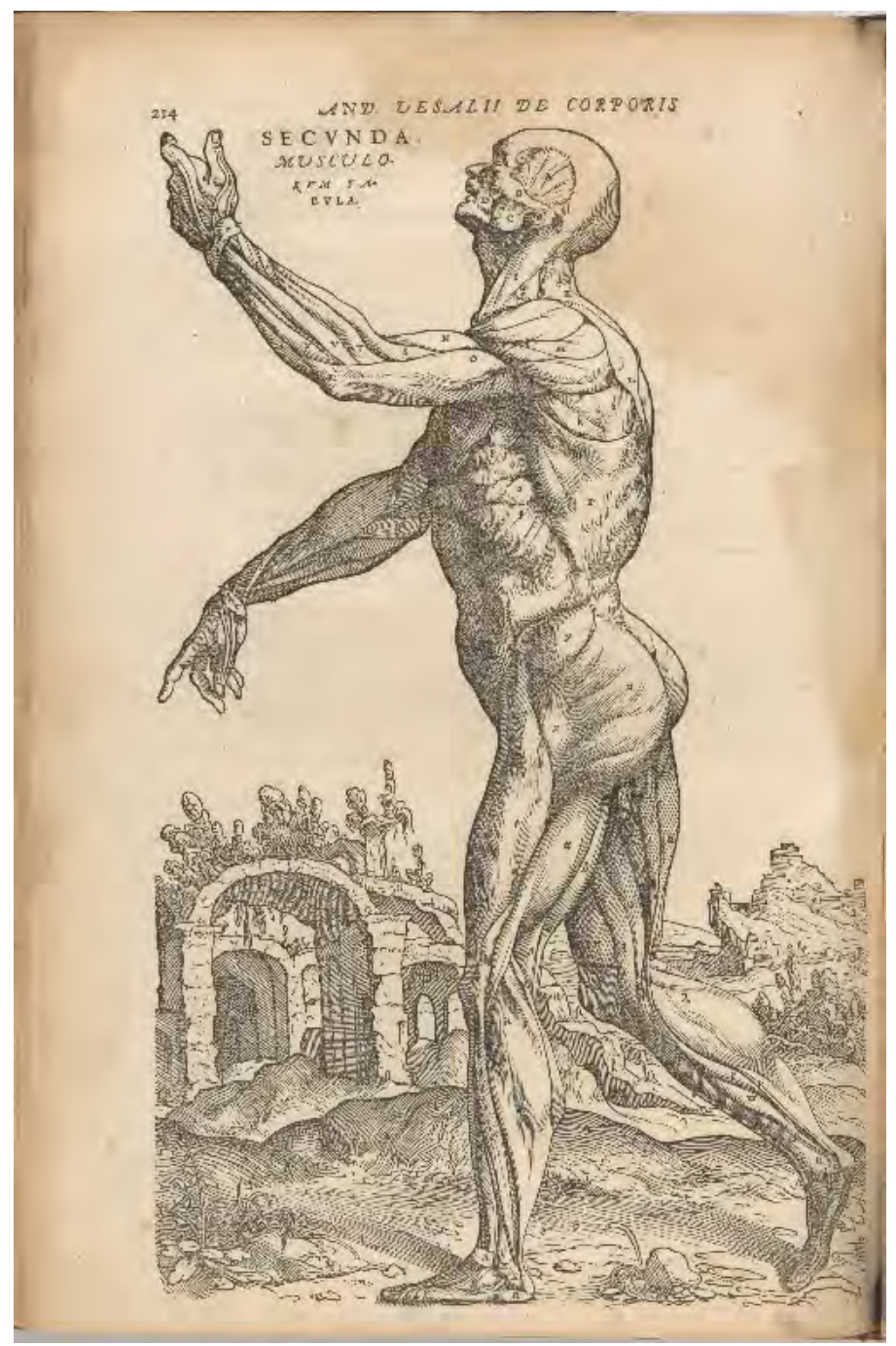

il. 1. Andreas Vesalius, De humani corporis fabrica, 1543 
Badania Wesaliusza opublikowane w roku $1543 \mathrm{w}$ De humani corporis fabrica (Bazylea, pracownia Johannesa Oporinusa; zob. Nierzwicki 2013) okazały się rewolucyjne również dla sztuki. Jego traktat został zilustrowany ponad 200 drzeworytami wykonanymi przez profesjonalnych artystów, wśród których był prawdopodobnie uczeń Tycjana, Jan van Calcar (The Metropolitan Museum of Art, b.d.). W części obrazów widać ciała w pozach sugerujących ich ziemską żywotność: stoją na tle krajobrazów, spacerują, przystają zamyślone. Jednocześnie są odarte ze skóry, rozcięte, z uchylonymi fragmentami tak, aby pokazały swoje wnętrza. Dla przykładu, w jednej z prac naga postać z zaznaczonymi mięśniami kroczy w stronę tajemniczej bramy, z głową uniesioną ku górze oraz rękami w geście sugerującym dyskusję (il. 1). Daniel Arasse $(2011,405)$ wśród inspiracji twórców zaznacza tradycję tańców śmierci, a w nawiązaniach do literatury i dzieł innych artystów wymienia między innymi Wygnanie z raju Masaccia, czy Hamleta Szekspira. Ten nowatorski sposób ilustrowania znajdzie potem sporo naśladowców. Zaspakaja on ciekawość tak wnętrza człowieka, jak i mechanizmów jego ruchów. Tego jak gesty lub chód zmieniają napięcia mięśni lub ułożenie kręgosłupa. Z kolei dla samych twórców ilustracji staje się okazją do uruchomienia wyobraźni, dotąd może nadmiernie skrępowanej ścisłą wiedzą.

Ryciny w ówczesnych anatomiach wzbogacają się o wyobrażenia, w których to zmarły pomaga odbiorcy zapoznać się z jego organami. Podobnie jak u Wesaliusza, ten rodzaj obrazów zobaczymy w publikacji, którą w 1545 roku wydał Charles Estienne (również uczeń Jacobusa Sylviusa): De dissectione partium corporis humani libri tres (Christies 2007). Jej ryciny sygnowali m.in. Stephanus Riverius oraz Jean Jollat. Na jednym z obrazów towarzyszących naukowym objaśnieniom widzimy kobietę podnoszącą ręką łożysko, by pokazać noszone w łonie bliźniaki. Estienne przygotował swój projekt już w latach 30. XVI wieku i gdyby, jak się przypuszcza, nie został wstrzymany posądzeniami o plagiat, byłby pierwszym przed Wesaliuszem autorem anatomii z rysunkami mającymi tak mocne metaforyczne odniesienia. Co ciekawe, wśród komentarzy i dyskusji towarzyszącym pracy Estienne’a były również te związane $\mathrm{z}$ inspiracjami w warstwie ilustracyjnej erotycznymi rysunkami Gli Amori degli dèi (Gian Giacomo Caraglio wg rysunków Perina del Vagi i Rossa Fiorentina, 1527). Nadawało im to specyficznego kontekstu połączenia erotyki i ginekologii, a prawdopodobnie wynikało z poszukiwania wzorców odpowiednio ułożonych ciał (Christies, 2007). 
Czasy wydania książki Wesaliusza wiążą się ze szczególnym zainteresowaniem artystów badaniami anatomicznymi. Niewątpliwie wynika to z wejścia w humanizm, a w sztuce w ambicje, by jak najlepiej i zgodnie z nauką odwzorowywać rzeczywistość. By to osiągnąć artyści pochylali się nad problemem ekspresji twarzy, ruchem, proporcjami, równocześnie podkreślając znaczenie wiedzy o budowie ludzkiego ciała. Leon Battista Alberti w traktacie $O$ malarstwie $(1435$, zob. Białostocki 1988,378 ) zalecał, by w pracy nad proporcjami postaci „najpierw zaznaczyć sobie w wyobraźni kości [...]. Następnie [...] zaznaczyć ścięgna i mięśnie, na koniec pokryć kości i mięśnie ciałem i skórą". Potrzeba wiedzy o budowie człowieka kusiła by bezpośrednio czerpać z doświadczeń sekcji zwłok. Według Vasariego dokonywał ich Antonio Pollaiuolo, a dobrym przykładem umiejętności odwzorowywania ciał przez artystę jest Bitwa nagich mężczyzn z ok. 1470 roku (za: Ważbiński 1972, 81). Nieoceniony wkład, w dużej mierze wynikający z badań nad zwłokami, wniósł w rysunek anatomiczny Leonardo da Vinci. Vasari pisał o Leonardzie (Vasari 1985, 23), że „oddał się z całym zapałem badaniom anatomii człowieka przy pomocy Marcantonia della Torre”, i że „Marcantonio posługiwał się w swych wykładach wynikami, rysunkami i ręką Leonarda, który wykonał całą książkę sepią i piórem, z rysunkami kości i muskułów spreparowanych przez siebie". W notatkach, zebranych później w Traktat o malarstwie, artysta zalecał: „Aby dobrze rozmieścić układ członków nagich w rozmaitych pozach i gestach konieczna jest dla malarza znajomość anatomii ścięgien, kości, muskułów i bicepsów, aby wiedzieć przy rozmaitych ruchach i napięciach, jakie ścięgno lub muskuł powoduje dany ruch” (por. Białostocki 1988, 578). Podobnie jak Leonardo, także Michał Anioł prowadził badania nieodebranych zwłok w szpitalu Santo Spirito we Florencji (Müntz 2007, 120). Buonarotti i jego osobisty lekarz Realdo Colombo planowali stworzyć atlas anatomii. Ostatecznie badania anatomiczne Colombo zostały wydane w pośmiertnej pracy De re anatomica (1559), bez ilustracji, jednak rycina jej strony tytułowej powstała prawdopodobnie na podstawie obrazu, którego twórcą był Paolo Véronèse. Anatomii zaczęto uczyć na uczelniach artystycznych, w drugiej połowie szesnastego wieku odpowiednie kursy proponowała florencka Accademia del Disegno i bolońska Accademia Carraci, a Accademia di Santa Luca w Rzymie oferowała je od 1607 roku (Laurenza 2012, 33). 


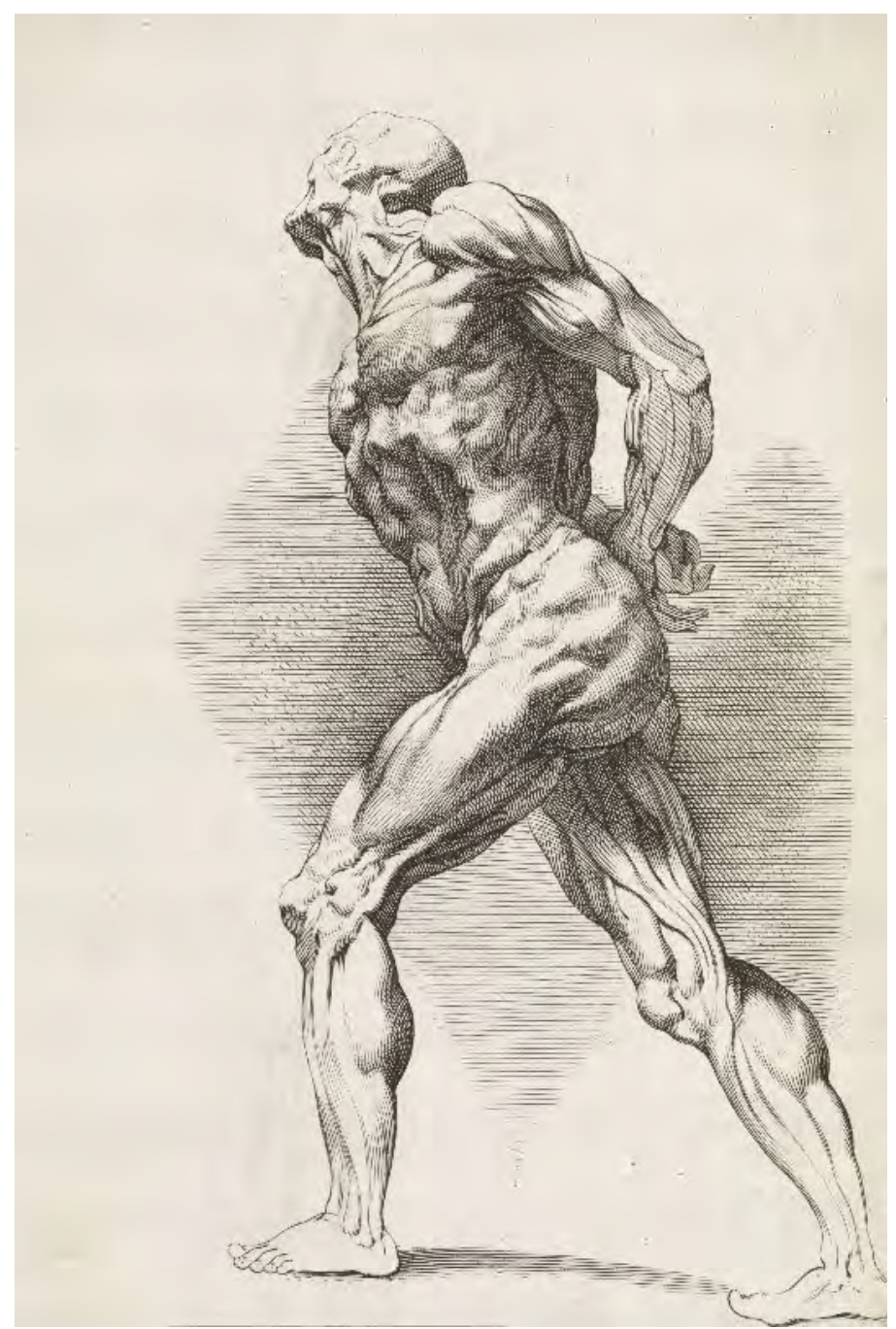

il. 2. Peter Paul Rubens, Studium anatomiczne stojącego mężczyzny, ryt Paulus Pontius, 1616-1657

Propagowaniem anatomii w atlasach z użyciem poetyckich ilustracji zajmował się również admirator dzieła Wesaliusza Juan Valverde de Amusco. Jego Historia de la composicion del cuerpo humano (wydana w Rzymie w 1560 roku) zawiera prace wzorowane na rycinach z dzieła wielkiego poprzednika, ale również odbitki z płyt Gaspara Becerra, który to z kolei inspirował się Michałem Aniołem (World Digital Library 2016). Podobnie bliskie w charakterze z racji ich narracyjnych nawiązań są ilustracje, których autorem jest Giulio Casserio (Tabulae Anatomicae, wydanie weneckie 1627 rok). Ich 
plansze zaprojektował Odoardo Fialetti. Postacie na jego obrazach prężą się, gną, układają i odsłaniają tak, by możliwie najpełniej zaprezentować omawiane partie ciała, elementy wnętrza i działanie organizmu (zob. National Library of Medicine 2016).

Bogato ilustrowane anatomie, w których postacie na obrazach będą poruszać się demonstrując swoją wewnętrzną urodę, będą towarzyszyły także kolejnym wiekom i badaniom. Wśród najważniejszych opracowań tego typu można wymienić dzieła Pietra Berrettiniego, zwanego Pietro da Cortona, który około 1618 roku przygotował serię dwudziestu rysunków anatomicznych na szarym papierze (Tabulae anatomicae opublikowana w 1741 roku w Rzymie). Z kolei w 1733 roku William Cheselden wydał w Londynie Osteographia, or the Anatomy of Bones wykorzystując w pracy nad dziełem po raz pierwszy kamerę obskurę. Niezwykłe wrażenie robią ilustracje Jacquesa Gamelina do tekstów opracowanych przez jego ojca Nouveau recuil d'ostéologie et de myologie dessiné après charakter (opublikowane w Tuluzie w 1779 roku). Prace Gamelina miały ponoć wspomóc tak przyszłych lekarzy, jak i artystów, istnieją również przypuszczenia, że stały się one inspiracją dla Kaprysów Goi (Hook i Norman 1991). Na obrazach widzimy sceny różnorodne i specyficzne: uczestniczą w nich szkielety i postacie odarte ze skóry (écorché), w tym dzieci i osoby dojrzałe. Są postacie grające na skrzypcach, usadzone na płycie nagrobnej, leżące na marach (jak Chrystus Holbeina), odpowiadające krzykiem na wołanie trąb. Stojące, leżące, klęczące, czasem w niezwykłych skrótach perspektywicznych. Na jednej z plansz spore wrażenie robi naga, anatomiczna postać zwisająca z krzyża (il. 3). W innej, w karczmie, w której odbywa się sowicie zakrapiana impreza grupa gości zabawia się grą w karty, podczas gdy na podeście przed nimi, zza odsłoniętej kurtyny-kotary, widać tańczącą dwójkę szkieletów. Warto dodać, że Jacques Gamelin uczył się w Art Académie Royale de Toulouse, studiował u Jacquesa-Louisa Davida i był głównym malarzem papieża Klemensa XIV.

Nie tylko tak niezwykle i bogato opracowywane książki dawały sposobność poznania ludzkiego ciała, sprzyjały temu także pokazy anatomiczne. Popularność zyskały teatry anatomiczne, których szeroki opis przestrzennej aranżacji przygotował Alessandro Benedetti (1502). Były one rozwinięciem idei demonstracji ciał, które wykonywano już wcześniej. W Bolonii prowadził je np. Mondiano de Liucci, później czynili to jego następcy i anatomowie na różnych uniwersytetach. Pierwszy stały amfiteatr anatomiczny 
powstał w 1584 roku w Padwie (Mandressi, 292), a kolejne teatry, w których za odpowiednią opłatą mogła uczestniczyć publiczność, pojawiły się np. w Pizie i Lejdzie. Zasłużoną sławą ze względu na projekt architektoniczny - wnętrze wyłożone drewnem, udekorowane rzeźbami przedstawiającymi słynnych medyków i anatomów (projekt: Antonio Levanti), cieszył się siedemnastowieczny boloński teatr anatomiczny mieszczący się w Palazzo dell'Archiginnasio.

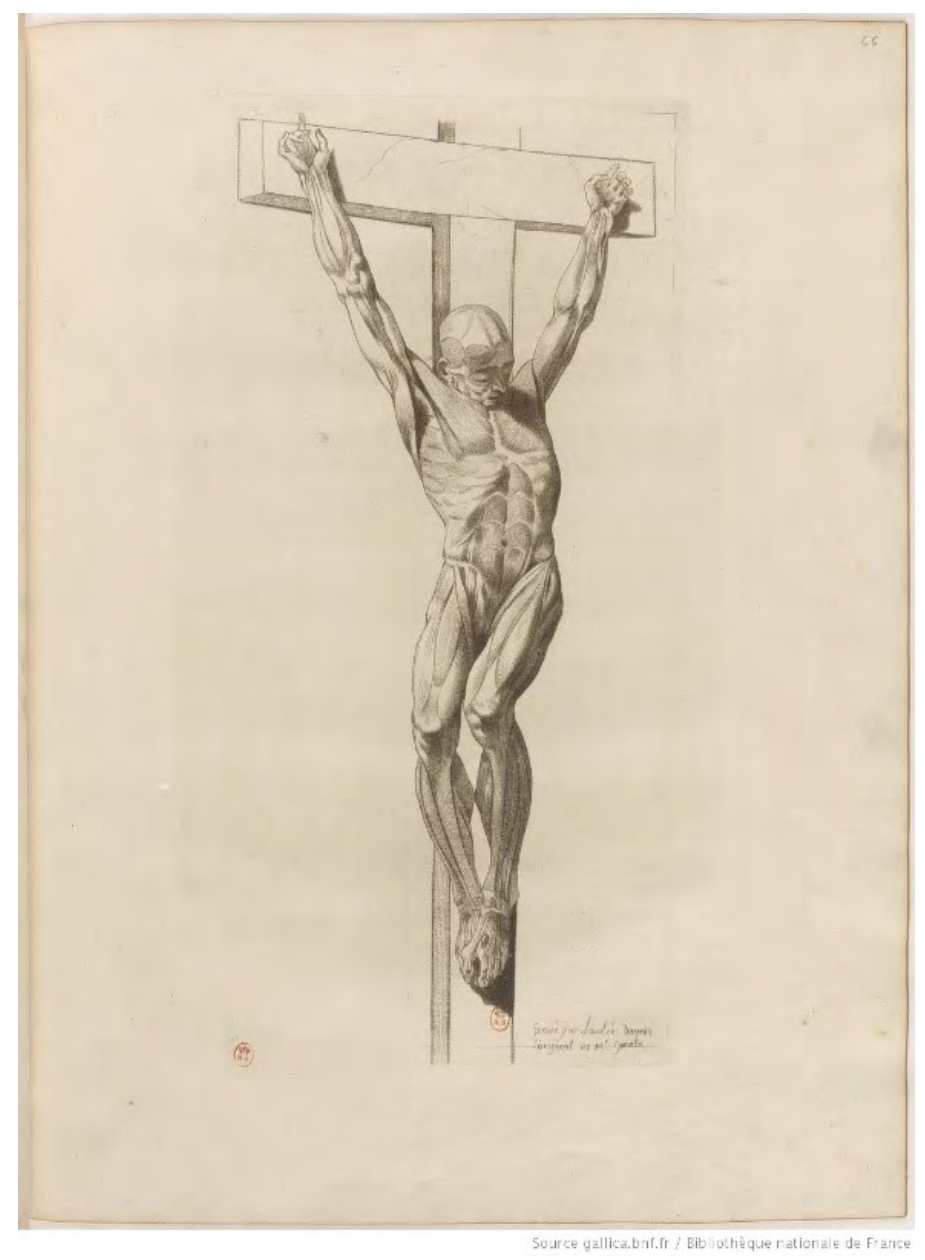

il. 3. Jacques Gamelin, Nouveau recuil d'ostéologie et de myologie dessiné après charakter, opublikowane w Tuluzie w 1779 roku 
W pomoc przy wyposażeniu takich obiektów angażowano artystów (zob. Düring, Didi-Huberman i Poggesi 1999). Przygotowywali oni rzeźby-modele pozwalające na demonstrację, a tym samym naukę anatomii. Niektórzy twórcy obiektów anatomicznych zdobyli dzięki nim międzynarodową sławę. Z uznaniem traktowano woskowe dzieła Gaetana Zumba (1656-1701), Sycylijczyka pracującego dla Kosmy III Medyceusza we Florencji, docenionego przez Ludwika XIV. Zumbo jest autorem rozbudowanych kompozycji ilustrujących ciała w rozkładzie, takich jak Dżuma z 1691 roku lub grupa Tryumf Czasu, Rozkład ciat i Syfilis - między 1691 a 1694 (Arasse 2011, 433). Prace artysty możemy dziś podziwiać w La Specoli, Sekcji Muzeum Historii Naturalnej we Florencji, w którym znajdziemy w nim również jedną z najsłynniejszych kobiecych figur anatomicznych zwaną Florenckq Wenus lub Wenus Medycejska. Jest to piękna niewiasta z otwartym wnętrzem ukazującym m.in. zapłodnioną macicę, a jej autorem jest Clemente Susini (ok. 1790) (Reilly 2014, 113). Wśród doskonałych przykładów realizacji rzeźbiarskich służących anatomii można wymienić Człowieka odartego ze skóry z 1767 roku. Wykonał go w wieku 25 lat Jean-Antoine Houdon, neoklasyczny twórca francuski, a jego dzieło pozostało przez stulecia popularnym modelem anatomicznym dla artystów (Fortenberry, Morrill i New 2015, 292).

Écorché Houdona to przykład rzeźby prezentującej ciało bez skóry, uwidaczniającej mięśnie. Realizacje tego typu stworzyli m.in. Willem van Tetrode (ok. 1560), Michael Henry Spang (ok. 1761, znane odniesienie do tego dzieła wykonał Edward Burch), a w zbiorach École Nationale Supérieure des Beaux-Arts w Paryżu znajdziemy écorché tańczące przypisywane Baccio Bandinellemu i datowane na koniec XVI wieku (Laurenza 2012, 45-46). Wśród odlewniczych, rzeźbiarskich dzieł przedstawiających budowę człowieka znajdujemy także prace alegoryczne i emocjonalne, np. woskowe figury chirurga André Pierre Pinsona (Siedzaca kobieta z końca XVIII wieku ze zbiorów Musée de l'Homme w Paryżu) (Arasse 2011, 435). Niejednokrotnie trudne w odbiorze woskowe dzieła budzą jednak mniejszy opór niż projekty mające konotacje artystyczne a korzystające z rzeczywistej materii ciała. Jednymi z bardziej znanych są écorché Honoré Fragonarda, kuzyna artysty Jeana-Honoré Fragonarda, który pracując w szkole weterynaryjnej w Alfort przygotowywał anatomiczne eksponaty preparując ciała (Écorché konia i jego jeźdźca, 1766-1771, il. 4). 


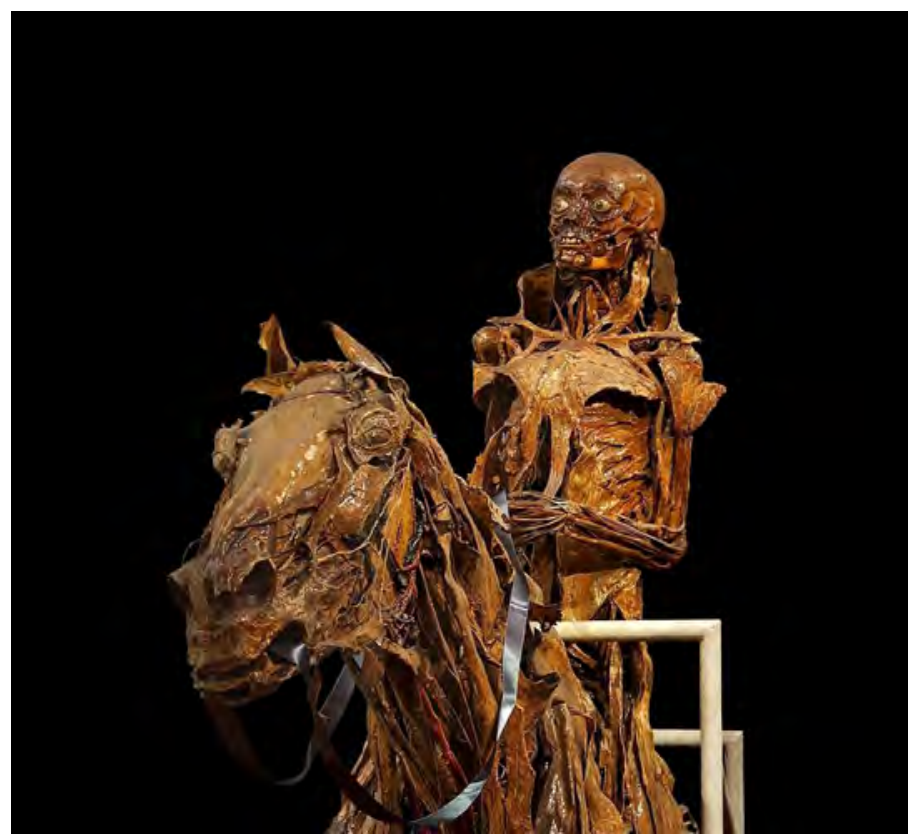

il. 4. Honoré Fragonard, Écorché konia i jego jeźdźca (fragment), 1766-1771, Museum Fragonard of the National Veterinarian High School of Alfort, Francja

Pokazy sekcji zwłok zyskiwały z czasem coraz szerszą publiczność i jak podaje Daniel Arasse $(2011,410)$ przyciągały „nie tylko umysły spragnione wiedzy, ale i publikę żądną sensacyjnych i bulwersujących rozrywek, zwłaszcza podczas uciech karnawałowych, kiedy ciało groteskowe wciąż jeszcze góruje nad ciałem nowożytnym”. Ciekawości wyglądu człowieka towarzyszyły w tych wiekach także ilustracje i, jeśli to było możliwe, pokazy, ludzi nietypowych, zdeformowanych genetycznie i chorobowo (Wieczorkiewicz 2009).

Zainteresowanie sekcjami zwłok wyraźnie widać również w dużych obrazach grupowych, rozpoczynających swoją historię od zamówień portretowych, w których elementem specyfikacji grupy stały się atrybuty zawodu. Wśród znanych przykładów można wymienić Rembrandta Lekcję anatomii doktora Tulpa z 1632 roku, jego Lekcję anatomii doktora fohna Deymana z 1656 roku lub Jana van Necka Lekcje anatomii doktora Frederika Ruyscha (1683). Wkład badań anatomicznych w sztukę widać także w wielu realizacjach pomnikowych, np. w nagrobku René de Châlona, który wyrzeźbił Ligier Richier (1547): wysoka na $170 \mathrm{~cm}$ postać francuskiego księcia wykuta w kamieniu 
zdumiewa precyzją budowy szkieletu (Fortenberry, Morrill i New, 404). Podobne wrażenie robi projekt nagrobka Katarzyny Medycejskiej, który za jej życia wykonał Girolamo della Robbia (1565), stworzony z takim realizmem w oddaniu ciała po śmierci, że ostatecznie Katarzyna nie zdecydowała się z niego skorzystać (Fortenberry, Morrill i New, 293).

Współpraca projektowa artystów i uczonych z czasem oraz z poszerzającą się dostępnością do badań owocowała częstszym przechodzeniem twórców z roli wykonawców na inicjatorów publikacji. Jak już zostało wspomniane wcześniej pochylanie się nad ciałem umocnione duchem nauki sprzyjało sztuce. Odkrywanie prawdy o materii tego najpopularniejszego motywu w koncepcjach artystycznych dawało pewność warsztatu i pozwalało czuć się swobodniej w bardziej osobistych dziełach. W konwencjach realistycznych umiejętność budowania ciała jest rodzajem testu. Elementy muszą się zgadzać, inaczej postać mogłaby nie ożyć, więc artysta-demiurg powołujący nowy byt powinien go odpowiednio ukształtować. By być pewnym budowy bohaterów obrazów ich twórcy poszerzali wiedzę i umiejętności nie tylko poprzez oficjalną współpracę z anatomami, ale też przez „badania własne", nie zawsze legalne. I tak na przykład Theodore Gericault miał korzystać z prawdziwych fragmentów ciał inspirując się nimi w swoich dziełach, czego dowodem są pozostawione studia malarskie, takie jak Głowa człowieka zgilotynowanego (1818-19).

Od II połowy XVII wieku artyści i naukowcy zaczęli podejmować odrębne projekty anatomiczne. Powstawały szkoły anatomii skupiające się na dydaktyce dla chirurgów oraz kursy anatomii artystycznej, drukowano także podręczniki anatomii przeznaczone dla artystów. W nauce zainteresowano się drobnymi strukturami, a możliwości badań nad nimi wzrastały wraz z rozwojem techniki (Laurenza 2012, 45). Rewolucją w wizualizacji badań nad człowiekiem i jego budową stała się fotografia, dzięki jej wynalazkowi w połowie XIX wieku można było tworzyć ilustracyjne plansze do anatomii na podstawie zdjęć, a wiedzę o ludzkim ciele wzbogacić o analizy faz ludzkiego ruchu3 ${ }^{3}$. Co ciekawe, mimo znaczących zmian w kulturze, fotografowie rozpoczęli dokumentacje chorób posługując się metodą bliską metaforycznym, nowożytnym ilustracjom rysunkowym. Nie ograniczali się do zmienionych chorobowo części ciała, ale pokazywali całego pacjenta patrzącego

3 Eadweard Muybridge wykonywał zdjęcia końskich skoków (opublikowane w Horse in motion $\mathrm{w} 1878 \mathrm{roku}$ ), a z końcem XIX wieku podjął studia nad ludzkim ruchem (por. Human Figure in Motion z 1901 roku) (Hoy 2006, 362). 
w obiektyw i demonstrującego na własnym przykładzie stan przed i po leczeniu (Hoy 2006, 358) (il. 5).

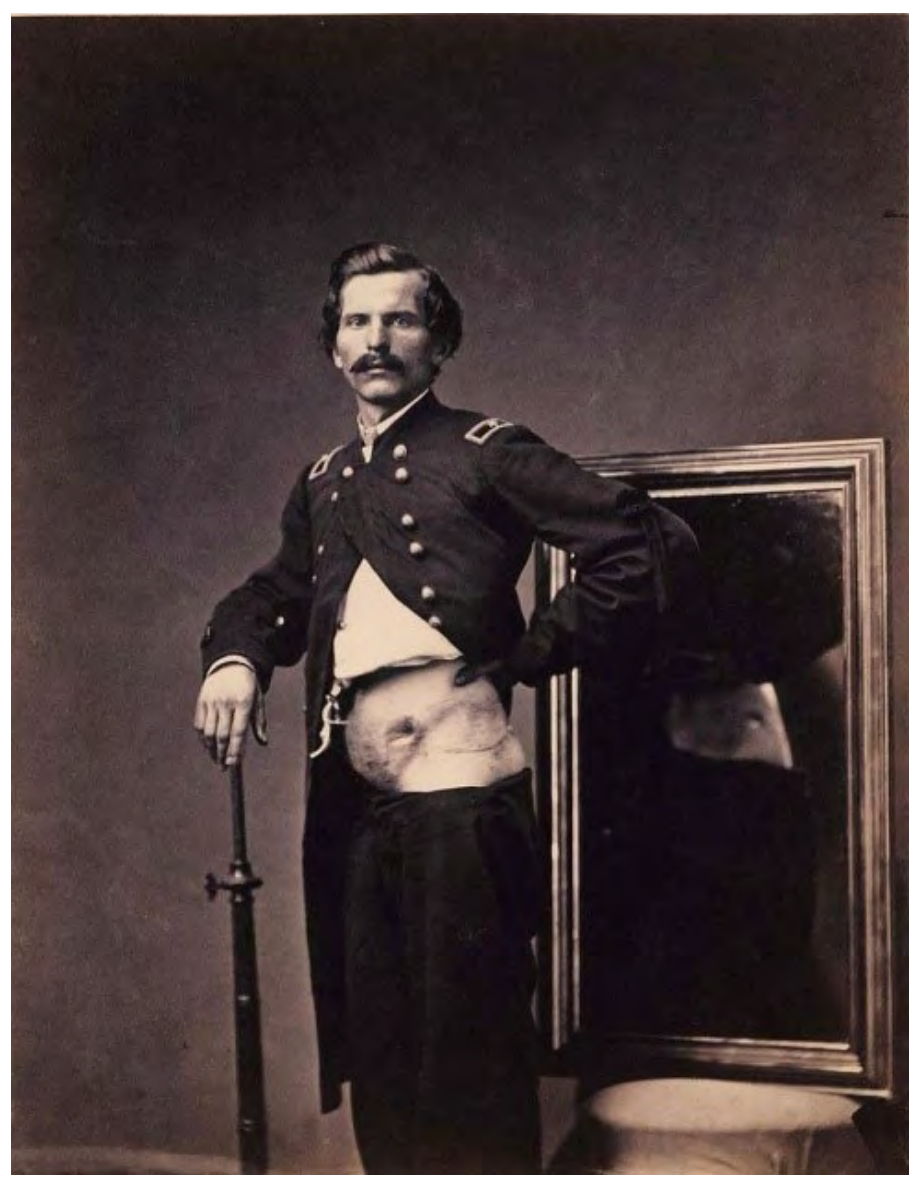

il. 5. William Bell, Major H. A. Barnum, Recovery after a Penetrating Gunshot Wound of the Abdomen with Perforation of the Left Ilium. W: Photographic Catalogue of the Surgical Section, 1865

Z uwagi na nowe możliwości, które przyniosła fotografia, koncepcje uzupełniania atlasów anatomii wyobrażeniami rysunkowymi bogatymi w treści poboczne stały się rzadsze, a ilustracje przybrały formy schematyczne (np. Bochenek 1953; Sinelnikov 1981). Z kolei współczesna nauka oferuje przyszłym lekarzom dodatkowe możliwości wizualizacji anatomicznej, jak cyfrowe modele wirtualnych pacjentów (zob. Wieczorkiewicz 2000, 209). Mimo postępujących zmian technologicznych profesjonalni artyści wciąż podejmują wysiłki przybliżania ludzkiego ciała w odręcznych studiach anatomicznych, 
choć coraz częściej służą one demonstracji warsztatu rysownika połączonego z podstawową wiedzą przydatną innym twórcom (np. Barcsay 1982; Simblet 2003).

Zarazem oryginalnie rozwiązane obrazy zawierające motywy operacji, nawiązania do sekcji zwłok czy też sięgające do innych elementów ilustracji anatomicznych (jak podziały, typologie, katalogi, schematy ruchu) są współcześnie obecne w sztuce, choć z innych powodów. Artyści nawiązują do nich niejednokrotnie nie $z$ chęci pokazania samego ciała, a bardziej po to, by poprzez ciało tak pokazane coś wyrazić. Tradycja metaforycznych anatomicznych ilustracji stała się odniesieniem wzmacniającym przekaz o fizyczności człowieka. $\mathrm{O}$ istocie materii, udziału ciała w bycie, o szansach, ale i niemożnościach przekroczenia ograniczeń ciała w codzienności. Wizja człowieka skoncentrowana na jego biologii może wzmacniać doświadczenie tknięcia prawdy. Materia jest zbadana, potwierdzona naukowo, a nawiązania medyczne i metaforyczne odniesienia mogą stanowić pewną drogę artystycznej wypowiedzi. Wśród cech dla niej charakterystycznych łączących ją z wielowiekowym doświadczeniem można wymienić prezentacje ciała, zwrócenie uwagi na jego elementy, budowę, funkcje i dysfunkcje.

Przykładem obrazów odwołujących się do anatomicznej tradycji wyrażającej się w demonstrowaniu ciała, chorób i ich leczenia mogą być prace artystów z kręgu Neue Sachlichkeit (Nowa Rzeczowość), ruchu figuratywnego z początku XX wieku. Christian Schad, którego interesowała rzeczywistość społeczna po I Wojnie Światowej, jest autorem obrazu przedstawiającego Agostę, człowieka z gołębią (odwróconą) klatką piersiową oraz Rashę, Czarną Gołębicę (1929). Pozujący do obrazu zarabiali w cyrku: mężczyzna demonstrując deformację ciała, Rasha występując z wężem. Dzieło Schada intryguje nietypową kompozycją (mężczyzna siedzący na fotelu patrzy na widza przybierając dumną pozę, podczas gdy na wysokości jego kolan, na wprost, spogląda z obrazu czarnoskóra modelka), a także „zgrzytającą” w kontekście tematu gładką manierą malarską (stylizowaną kreską, klasycznym światłocieniem). Ciekawość „dziwnych ludzi”, tak kłócąca się z ideą elitarnego społeczeństwa, wybór do publicznych pokazów człowieka z chorobą i czarnoskórej piękności, obnażały zakłamanie. Artysta zbudował zaangażowany przekaz nieschematycznie, bez dynamicznej ekspresji a posługując się dość klasycznym portretem (zob. Voermann 2012, 44). Również z 1929 roku pochodzi praca Schada pod tytułem Operacja. W harmonijnej kompozycji malarskiej artysta pokazuje pacjenta, nad którym pochylają się lekarze 
i pielęgniarki. Wszystko jest tu stonowane, dużo bieli zwiększa poczucie sterylności, co uświadamia, że operowany człowiek jest przedmiotem procedur medycznych.

„Lekarskie” kompozycje znajdziemy również w dorobku Otto Dixa. W 1927 roku artysta namalował swojego syna zaraz po narodzinach: na płótnie widzimy pomarszczonego niemowlaka unoszonego na białej chuście (il. 6). Z pozoru liryczny temat został tu potraktowany z bezwzględnością malarską - dziecko jest odkształcone po porodzie, nadmiernie czerwone. Artysta nie upiększa, konfrontuje romantyczne wyobrażenia odbiorcy z rzeczywistością porodu i wyglądem noworodka tuż po przyjściu na świat.

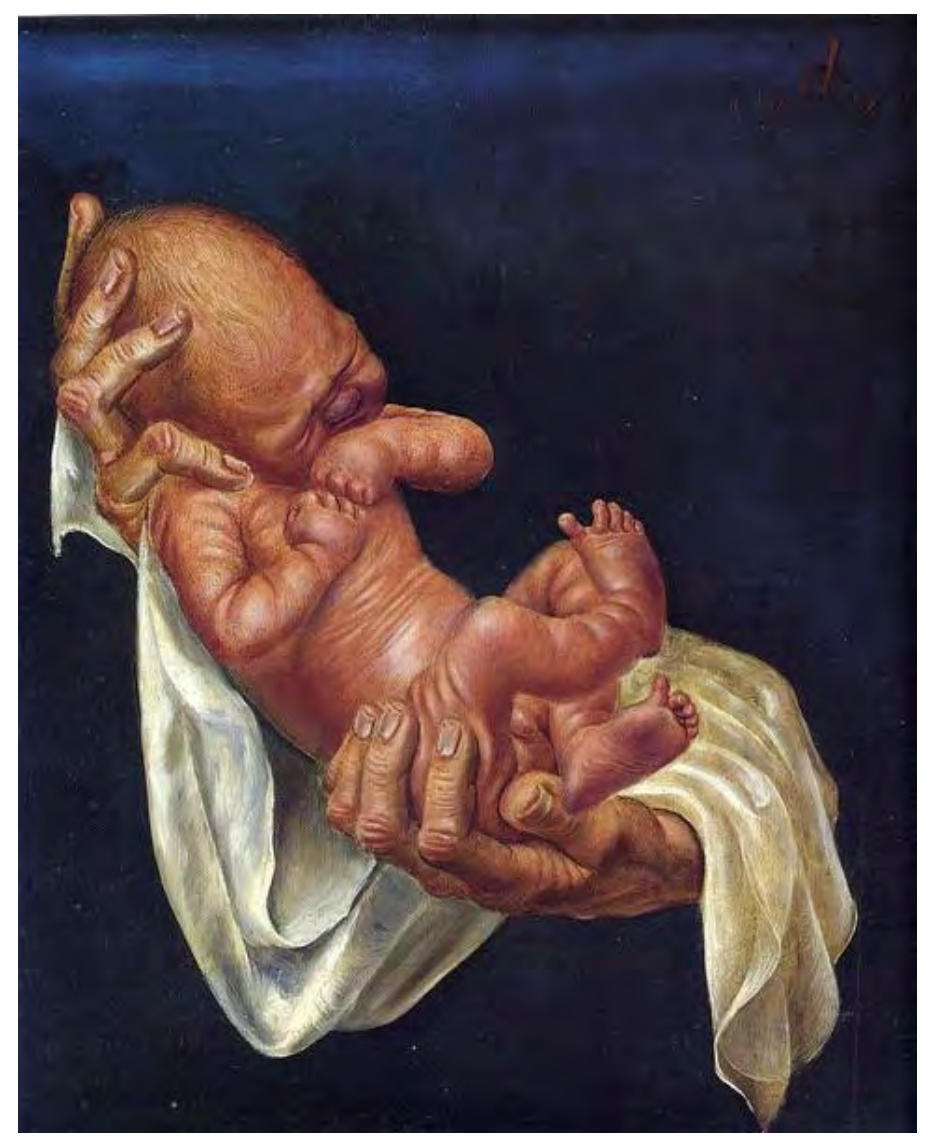

il. 6. Otto Dix, Neugeborenes Kind aufHänden (Ursus), 1927, ๑ VG Bild-Kunst, Bonn 2020

Operacje i ich efekty znajdziemy także kilkadziesiąt lat później w projektach artystów komentujących rzeczywistość w ruchu Krytycznego Realizmu. 
Liczne obrazy przedstawiające zabiegi, sterylnie opracowane w technice malarskiej na podstawie fotograficznych dokumentacji, pozostawiła Maina-Miriam Munsky (zob. Bulk 2012, 109). Jej prace - wyobrażające sytuacje medyczne widziane z różnych punktów sali operacyjnej, czasem pokazujące całość grupy lekarskiej, czasem tylko fragmenty ciała sugerujące konkretny typ ingerencji chirurgicznej - są, mimo ich pozornej estetyzacji, niezwykle ekspresyjnym głosem o kruchej kondycji człowieka, nieubłagalnie niezależnej od jego planów i ambicji.

Fotograficzna i filmowa dokumentacja operacji może towarzyszyć artystycznym działaniom dotyczącym fizycznych zmian ciała zdarzających się „na życzenie”. Jednym z przykładów jest twórczość radykalnej artystki Orlan. Jej przydomek artystyczny kojarzony jest z wieloletnim projektem dążenia do uniwersalnego piękna, który miał zrealizować się poprzez szereg zabiegów. Z kolei Anette Messager w pracy Voluntary Tortures (1972) zestawia zdjęcia osób poddających się mniej lub bardziej inwazyjnej ingerencji w ciało związanej z przemysłem piękna (Reckit 2012, 106). Na fotografiach zmieniającego się ciała bazuje projekt Eleonory Antin (1973), udokumentowała w nim przemiany w wyglądzie postępujące wskutek jej restrykcyjnej diety (Reckit 2012, 85). Problem współczesnej opresji piękna podejmują także artyści wypowiadający się w technikach tradycyjnych, np. Jenny Saville w pracy olejnej pt. Plan (1993) pokazuje widziane od dołu, przeskalowane ciało kobiety, na którym zostały zakreślone linie sugerujące zbliżający się zabieg liposukcji (Fortenberry, Morrill i New, 45). Zagadnienie represji społecznej związanej z narzucanym globalnie typem doskonałości urodowej wybrzmiewa często w sztuce feministycznej. Katalogowanie, rejestracja zmian fizycznych wynikających z mniej lub bardziej dobrowolnych zabiegów przemysłu piękna towarzyszy tu także projektom skłaniającym do refleksji nad bagatelizowaniem schematów związanych z rolami społecznymi i płcią. Zoe Leonard w pracy prezentowanej w ramach Documenta IX w Neue Galerie w Kassel (Untitled, 1992) kilkusetletnie portrety zachwalające kobiecą zmysłowość zestawiła z „medycznymi” zdjęciami prezentującymi wprost kobiece genitalia (Reckit (Ed.) 2012, 166). W innej pracy Zoe Leonard (il. 7) został uchwycony, w ukośnym kadrze, woskowy model anatomiczny kobiety. Dekoracja obiektu sznurem pereł na szyi i jej długie włosy skłaniają, według artystki, do pytania o rolę ekspozycji anatomicznych w kontekście dominacji płci (zob. Cottingham 1993). 


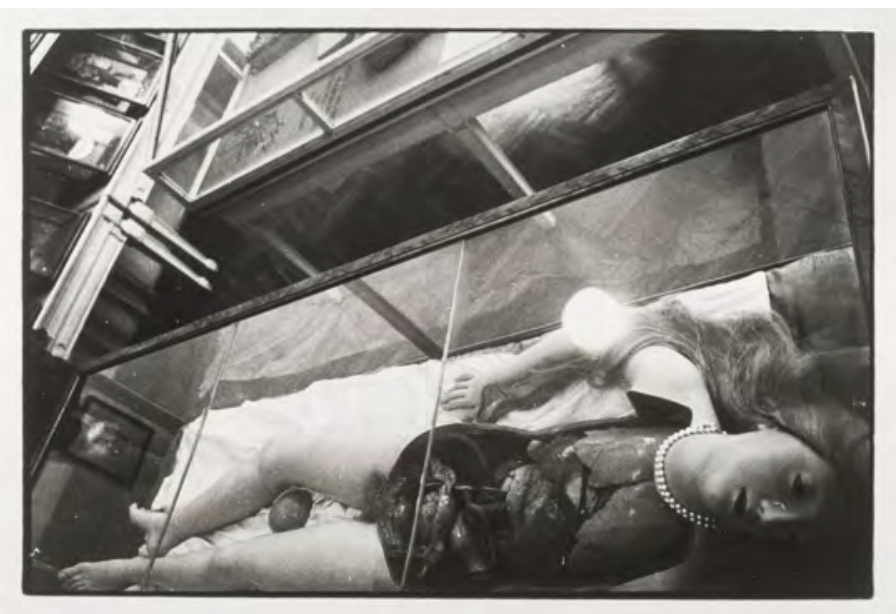

il. 7. Zoe Leonard, Wax Anatomical Model (Shot Crooked from Above), 1990, (c) Courtesy Zoe Leonard and Galerie Gisela Capitain, Cologne

Idea ukazania, zderzenia $\mathrm{z}$ cielesnością towarzyszy fotograficznym dokumentom-ekspozycjom ciała artysty poddawanego operacji, w trakcie leczenia, ciała wyniszczanego śmiertelną chorobą. Obcując z projektem, którego wykonawczynią i modelką była Hannah Wilke, jesteśmy świadkami walki artystki z chłoniakiem. Na zdjęciach z serii Intra Venus z lat 1992-1993 oglądamy ją po zabiegach. W jednej z serii nieupozowana, naga kobieta leży na białym posłaniu, ubrana-oblepiona jedynie plastrami umocowanymi na wysokości bioder i dolnej partii grzbietu (Fortenberry, Morrill i New, 43). Z kolei Mark Morrisroe w zestawie autoportretów powstałych około 1989 roku demonstrował swoją fizyczność i jej ułomność postępującą z czasem w wyniku zachorowania na AIDS. Na jednej z fotografii nagi mężczyzna, leżący na łóżku między przedmiotami codziennego użytku, zatrzymuje wzrok chudością i wyniszczeniem. Jego widocznie zarysowane żebra, kościste biodra, nienaturalnie szczupłe nogi świadczą o postępującej biologicznej degradacji i kojarzą się tak z obrazami umierania, jak i powstałymi po wojnie dokumentacjami osób wyzwolonych z obozów koncentracyjnych (Fortenberry, Morrill i New, 293).

W drugiej połowie XX wieku znajdziemy także inne motywy znane z rysunków anatomicznych: szkielety, ciała bez skóry, dysfunkcje ciała, jego fragmenty. I tak, wnętrznościami - mięsem, ścięgnami, krwią, wielokrotnie inspirował się w swoich dziełach Francis Bacon (np. Ukrzyżowanie, tryptyk z 1965 roku), dla którego „mięso” było symbolem dotykalnej, brutalnej 
rzeczywistości ${ }^{4}$. Po szkielety, w performansach i projektach fotograficznych, sięga Marina Abramović (Niosq̨c szkielet, 2008). Korzystając w nich z nawiązań do tradycji vanitas artystka zaznacza kruchość życia, ale i fizyczność człowieka. Intrygujące odniesienia do dzienników chorób, anatomicznych rzeźb i rysunków znajdziemy w dorobku Aliny Szapocznikow. Artystka, która przeżyła w dzieciństwie pobyt w obozach nazistowskich, w młodym wieku poważnie chorowała, a w ostatnich latach życia walczyła z rakiem, tworzyła polimerowe odlewy swojego ciała zawierające między innymi zmiany nowotworowe. Szapocznikow w drugiej połowie lat 6o. XX wieku zaczęła pracę $\mathrm{z}$ odlewami, najpierw brzucha i ust, potem tworząc instalacje $\mathrm{z}$ fragmentami ciała toczonego chorobą, w tym serię Nowotwory. W 1971 roku na wystawie w Paryżu pokazała Pogrzeb Aliny. Rok później zaczęła tworzyć cykl Herbariums (Zielniki), w którym modelem był jej syn Piotr (zob. Jakubowska 2012). Wydaje się, że gros dzieł artystki, szczególnie tych odlewanych, nie ilustruje, ale oddaje wprost wygląd ciała zmienionego chorobą. Jest dowodem konkretnego istnienia, obiektywnym na tyle, na ile jest to możliwe, w bądź co bądź subiektywnej z natury rzeczy, sztuce.

„Preparaty z ludzkich ciał, służące studentom do nauki anatomii, pokazują, jak ciekawym, skomplikowanym i ciągle odkrywanym mechanizmem jest ludzkie ciało" - piszą autorzy wystawy Medycyna w sztuce eksponowanej w MOCAK-u (Jałowik, Kozioł i Potocka 2016, 182). Idea ciała oddanego nauce, ciała jako dowodu medycznego, a równocześnie ciała które kiedyś komuś służyło, jest widoczna w serii Collegium Anatomicum Konrada Kuzyszyna (il. 8). „Z końcem 1988 roku” - pisze autor o powstaniu projektu „wszedłem do Collegium Anatomicum Akademii Medycznej w Łodzi. Zobaczyłem ludzkie preparaty, służące studentom do nauki anatomii prawidłowej. Nigdy wcześniej nie doznałem tak silnego lśnienia egzystencjalnej reprezentacji, w humanistycznej a zarazem metaforycznej formule. Żadna forma bytu nie wniknęła tak brutalnie ale i głęboko w moją świadomość” (Kuzyszyn, 10). Na czarno-białych zdjęciach artysty pokazane są obiekty - ludzkie ciała z wyciętymi wnętrznościami, z otwartą powłoką brzuszną ${ }^{5}$. Widzimy ciała podtrzymywane linkami, fragmenty ciał w słojach, zanurzone w formalinie. Przez kabiny i słoje przechodzi światło i opływając nieruchome ciała wydaje

4 Wcześniej podziały ciała bliskie koncepcji dzieł Bacona znajdziemy np. u Picassa, w serii szkiców-studiów związanych z obrazem Ukrzyżowania z 1930 roku, a pochodzących z 1932 roku (Baldassari 2005, 148-149).

5 3o lat po tej pierwszej wizycie Konrad Kuzyszyn pokazał w Galerii Piekary w Poznaniu zdjęcia z ponownej sesji w Collegium, tym razem w kolorze. 
się wzmacniać poczucie ich wiecznego trwania. Ich naruszenie, otwarcie powłok zderza odbiorcę z wielowiekową tradycją nietykalności zmarłych.

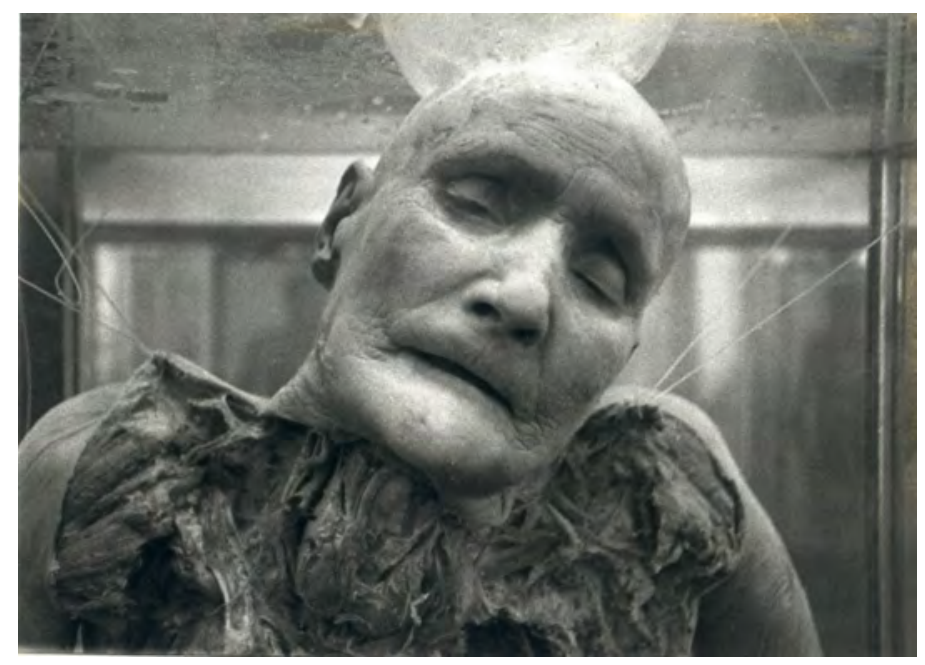

il. 8. Konrad Kuzyszyn, z cyklu Collegium Anatomicum 1, 1988-89

Estetyczne relacje bohatera o dysharmonicznym, naruszonym chorobą ciele i pięknej fotografii widać w projektach artystycznych, których autorką jest Milja Laurila. Fińska artystka inspiruje się encyklopediami zdrowia oraz atlasami chorób i tworzy cykle fotograficzne, w których „odbiorca może w zależności od wiedzy dostrzec objawy schorzenia bądź piękno ciała” (Jałowik, Kozioł i Potocka 2016, 184), jak w serii osób cierpiących na skoliozę, il. 9, 10). W swoich projektach Laurila na wzór fotografii dokumentalnej pokazuje postacie niespełniające schematycznych warunków estetycznych, jednak przez nienachalność i surowość kompozycji buduje poczucie godności i prawdziwości bohaterów. Fotografie zestawione w układach kojarzących się z dokumentacją szpitalną tworzą instalacje potęgujące świadomość złożonej fizyczności człowieka. 


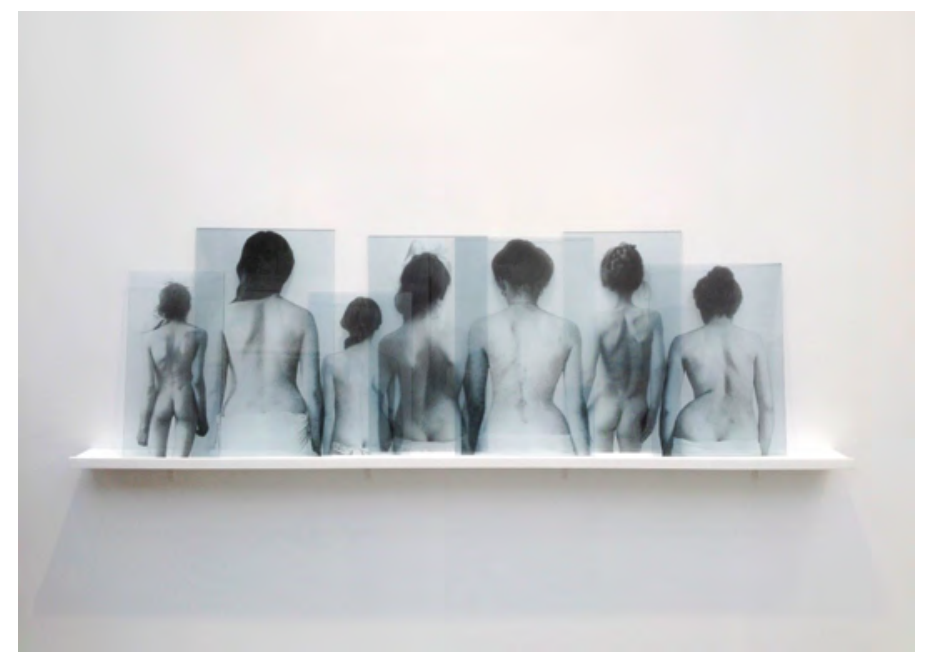

il. 9. Milja Laurila, Observatory, 2015, 7 UV prints on $4 \mathrm{~mm}$ acrylic glass, shelf $57 \times 190 \mathrm{~cm}$, Edition 5

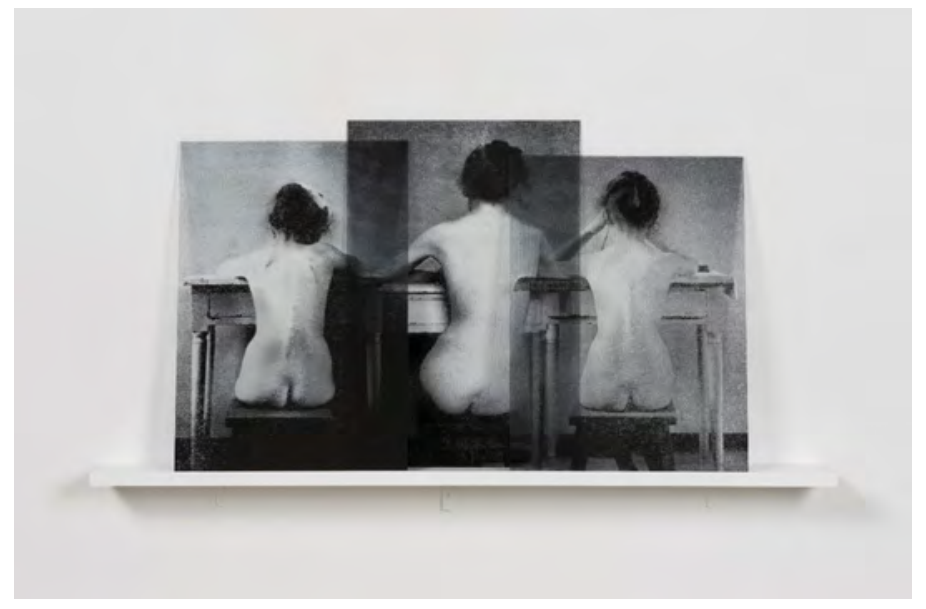

il. 10. Milja Laurila, In Their Own Voice, 2016, 3 UV prints on $4 \mathrm{~mm}$ acrylic glass, shelf $60 \times 130 \mathrm{~cm}$, Edition 5, Photo: Marcus Schneider

Dokumenty odchodzenia i zmarłego ciała są przedmiotem projektów społeczno-artystycznych pary Walter Schels i Beate Lakotta. Na zdjęciach widzimy osobę chorującą - za życia i po śmierci, a fotografie uzupełnione są o wywiady z bohaterami cyklu, świadomymi terminalnej fazy ich choroby. $\mathrm{Z}$ kolei fotografie z prosektorium wchodzą w głośny projekt Andresa Serrano: The Morgue, 1992 rok. Na zdjęciach znajdujemy ofiary chorób, osoby zmarłe w wypadkach, wskutek morderstw i samobójstw (il. 11). Szczególne 


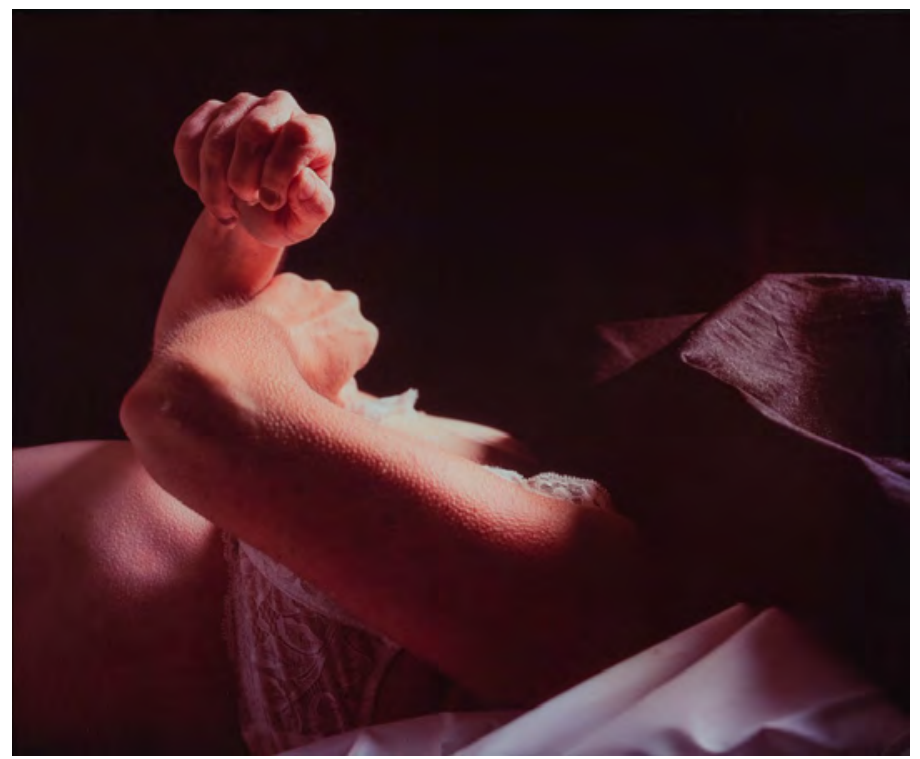

il. 11. Andres Serrano, Rat Poison Suicide (de la série «The Morgue »), 1992. Épreuve Cibachrome, 1/3 / Cibachrome print, 1/3, 125,7 x 152,3 cm / 125,7 x 152,3 cm. Collection Musée d'art contemporain de Montréal, (c) Andres Serrano. Photo: Richard-Max Tremblay.

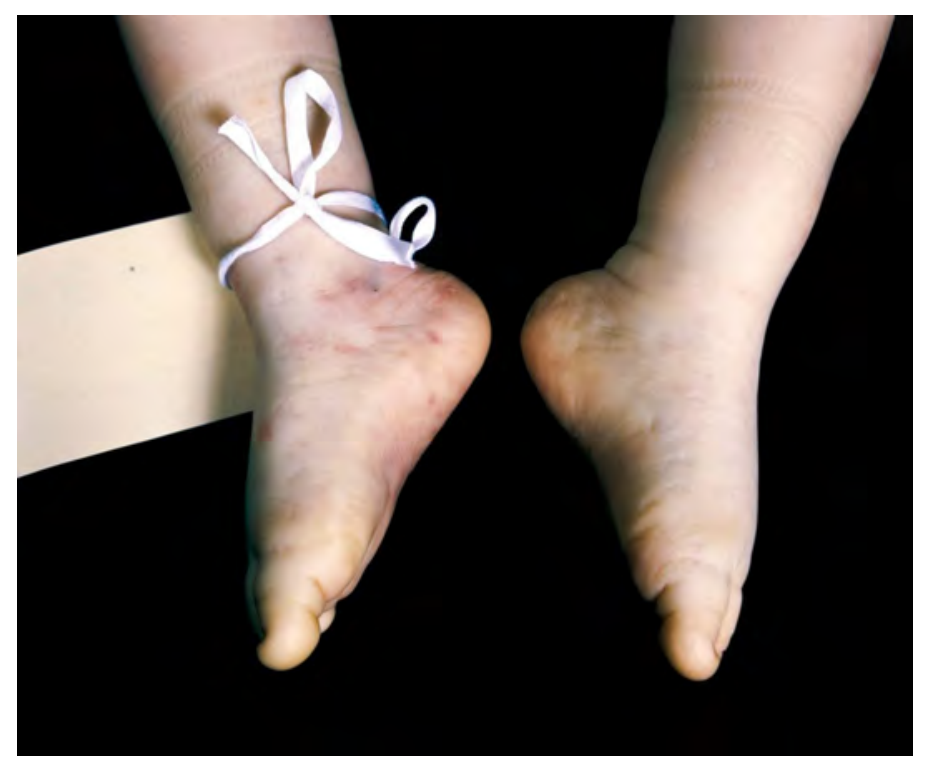

il. 12. Andres Serrano, Fatal Meningitis, 1992, courtesy of the artist and Nathalie Obadia galery 
wrażenie robią ciała zmarłych dzieci, np. fotografia małych stóp oznaczonych identyfikatorem (il. 12). Doskonale oświetlone postacie leżące na prosektoryjnym stole, precyzyjnie zarysowane, kontrastowo zestawione z ciemnymi tłami pokazują fizyczność i biologiczną nietrwałość - widzimy ją w kolorze ciała, w ranach, w plamach opadowych.

W zestawieniu odwołań w sztuce do prezentacji ciała zmienionego należy wymienić także działania performatywne sugerujące lub rzeczywiście naruszające ciało. Wśród nich są projekty akcjonistów wiedeńskich - realizowane w bezpośrednim kontakcie z widzem, prezentujące przebieg destrukcji i jej skutki na żywo (a także na fotografiach i w filmach). Ciało, jak pisze o austriackich akcjonistach Hanno Millesi $(2011,135)$, stanowi w ich sztuce ważny punkt odniesienia, ,jego podatność na obciążenie i zranienie, reprezentowana przez nie bariera wobec świata zewnętrznego, ale także związana z nim społeczna dyspozycja jako obiektu represji i gwaranta możliwości zidentyfikowania”. W kontekście tradycji zestawiania dokumentów ciała charakterystycznych dla ilustracji w anatomii, ciało jako pozajęzykowy sposób komunikacji, sfotografowane i skatalogowane, stało się podstawą projektu Kadrowanie ciałem Wiktora Gutta i Karola Radziszewskiego (1975). Ten model konstruowania projektów artystycznych na podstawie zestawienia zdjęć demonstrujących ciało i jego fragmenty, jego ruch i ułożenie (opisany już wcześniej przy omawianiu kilku innych prac), znajdziemy u wielu artystów tworzących na przełomie XX i XXI wieku (np. Andrzej Kokoszka, Skanowanie intymne z 2003 roku). (Świtek 2004).

$\mathrm{Na}$ liście projektów inspirowanych dziełami pokazującymi badania nad ciałem są również prace $\mathrm{z}$ wyraźnymi nawiązaniem do tradycji tego rodzaju przedstawień, np. temat sekcji zwłok występował w rysunkach i obrazach, których autorem był amerykański malarz Edgar Levy (Sekcja zwłok, 1938), a odniesienia do lekcji anatomii Rembrandta znajdziemy np. u Tadeusza Kantora (Lekcja anatomii wedle Rembrandta, happening, zapis filmowy 1969) czy później u Grzegorza Kowalskiego (Kompilacja, 1977).

Z powyższej listy współczesnych projektów artystycznych i ich autorów podejmujących motywy znane $\mathrm{z}$ anatomicznych rysunków (lub innych obiektów wspierających rozwój i popularność wiedzy o ciele), wynika, że konstrukcja ciała, jego funkcje i dysfunkcje są pociągającym, z wielu różnych powodów, tematem w sztuce. Powszechna ciekawość, którą wzbudza ludzkie ciało (czego prostym i poniekąd zastanawiającym dowodem może 
być popularność kontrowersyjnych realizacji Gunthera von Hagensa ${ }^{6}$ ) można wykorzystać, prowokując do zastanowienia się i dyskusji: o granicach człowieczeństwa, o nietrwałości, o kruchej egzystencji, o etapach ludzkiego życia. Hasła: wszyscy jesteśmy mięsem, jesteśmy zbudowani jak zwierzęta, mamy nietrwałe, umierające organy, wpisują się w szereg dyskutowanych problemów społecznych o potencjalnie długiej aktualności. Ciało jako obiekt upokarzania, molestowania, ciało jako dowód nierówności społecznej, ciało wykluczane, ciało niemodne jest przedmiotem sztuki krytycznej, sztuki zaangażowanej. W świecie, w którym istotne znaczenie ma dynamiczny rozwój technologiczny coraz wyraźniejszym tematem jest także ciało niedostosowane oraz potencjalne ciało doskonałe - doposażone w niezbędne cyfrowe akcesoria (zob. Bodzioch-Bryła 2015). W projektach artystycznych dotykających pięknej a równocześnie tymczasowej, trawionej chorobami ludzkiej powłoki, wybrzmiewa także wielowiekowa tradycja koncepcji odnoszących się do ludzkich ambicji i aspiracji zamkniętych w ciele ulegającym niemocy - tracącym z wiekiem sprawność, toczonym bolączkami zgodnie z rytmem praw biologicznych.

Wobec tak dużego pola „medycznych” odniesień w sztuce, ich miejsce wydaje się na lata niezagrożone. Temat ciała, jego budowy i wszystkiego, co z nim się wiąże, będzie bowiem wciąż fascynował, tak z powodu jego niezwykłej doskonałości, jak i zarazem, niedoskonałości - kiedy ciało nie daje rady sprostać nowej rzeczywistości, choruje, jest odrzucane, a ostatecznie umiera.

6 Gunther von Hagens, profesor z Heidelbergu, opracował metodę konserwacji anatomicznej - plastynacji, w oparciu o nią przygotował obiekty z ludzkich ciał (wg informacji autora - donatorów), które eksponuje od końca lat 9o. XX wieku na wystawach. Jak wskazuje Anna Wieczorkiewicz, wystawy preparatów Hagensa naruszają społeczno-kulturowe wielowieczne tabu, a ich hasłem reklamującym jest autentyczność, która wynika z obcowania z martwym ludzkim ciałem. Von Hagens nie wystawia w przestrzeniach artystycznych, a jednocześnie podkreśla idee pokazywania ludzkiego piękna (Wieczorkiewicz 2000, 210-218). 


\section{Bibliografia}

Abramović, Marina. 2018. Pokonać mur. Wspomnienia. Tłum. Anna Bernaczyk i Magdalena Hermanowska. Poznań: Rebis.

Alberti, Leon Battista. 1435. „O malarstwie”. Tłum. Lidia Winniczuk. W Myśliciele, kronikarze i artyści o sztuce od starożytności do 1500 roku, red. Jan Białostocki, 358-391. Warszawa: PWN.

Arasse, Daniel. 2011. „Ciało, wdzięk, wzniosłość”. Tłum. Tomasz Stróżyński. W Historia ciała. Tom I. Od renesansu do oświecenia, red. Georges Vigarello, 379-439. Gdańsk: słowo/obraz-terytoria.

Baldassari, Anne. 2005. Bacon - Picasso. The life of images. Tłum. z j. franc. na j. ang. David Radzinowicz. Paris: Flammarion.

Barcsay, Jenő. 1982. Anatomy for the artist. Békéscsaba: Kner Printing House, Dürer Workshop.

Benedetti, Alessandro. 1502. Anatomice: sive, de historia corporis humani libri quinque. Wenecja.

Bochenek, Adam. 1952. Anatomia człowieka, Tom I. Anatomia ogólna. Kości, stawy $i$ więzadła. Warszawa: Państwowy Zakład Wydawnictw Lekarskich.

Bodzioch-Bryła, Bogusława. 2015. „Smakosze kultury. Pomiędzy przeszczepem a artystycznym doświadczeniem. Przeobrażenie figury ciała ludzkiego w sztuce XX i XXI wieku pod wpływem mediów”. W Bogusława Bodzioch-Bryła, Lilianna Dorak-Wojakowska, Michał Kaczmarczyk, Adam Regiewicz, Przeptywy, Protezy, przedtużenia... Przemiany kultury polskiej pod wptywem nowych mediów po 1989 roku, 49-79. Kraków: Akademia Ignatianum w Krakowie, Wydawnictwo WAM.

Bulk, Julia. 2012. „The Reception of New Objectivity in the 1960s and 1970s”. W Otto Dix and the New Objectivity, red. Ilka Voermann, 98-112. Stuttgart: Künstmuseum Stuttgart we współpracy z Staaliche Akademie der Bildenden Künste, Hatje Cantz.

Christies. 2007. Berengario da Carpi, Giacomo. Isagogae breves perlucide ac uberrimae in Anatomiam humani corporis. Bologna: Benedictus Hectoris, 15 July 1523. Dostęp: 13.11.2019.

Christies. 2007. Estienne, Charles (ca 1505-1564). De dissectione partium corporis humani libri tres. Un cum figuris, \& incisionum declarationibus, Stephano Riverio Chirurgo compositis. Paris: Simon de Colines, 1545. Dostęp: 12.11.2019. 
Cottingham, Laura. 1993. „Zoe Leonard”. fournal of Contemporary Art 6(1): 64-77. Dostęp: 20.05.2020.

Cunningham, Andrew. 2016. The Anatomical Renaissance. Routledge: London and New York.

von Düring, Monika, Georges Didi-Huberman i Marta Poggesi. 1999. Encyclopaedia Anatomica: a complete collection of anatomical waxes. New York: Taschen.

Fortenberry, Diane, Rebecca Morrill i Josephine New. 2015. Body of Art. London: Phaidon.

Gryglewski, Ryszard W. 2016. Rola czynników kulturowych w kształtowaniu się badań anatomicznych opartych o autopsję ludzkiego ciała. „Kultura i Historia" 29: 51-70. Dostęp: 20.05.2020.

Hoy, Anne H. 2006. Wielka księga fotografii. Tłum. Marta Suwała-Posłuszna, Maciej Posłuszny i in. Warszawa: National Geographic, Wydawnictwo G+J RBA.

Hook, Diana H. i Jeremy M. Norman. 1991. The Haskell F. Norman Library of Science and Medicine. Za: Julie L. Mellby. 2010. Nouveau recueil d'ostéologie et de myologie (A New Collection of Bones and Muscles). 24.02.2010. Dostęp: 10.11.2019.

Jakubowska, Agata i Katarzyna Szotkowska-Beylin, red. 2012. Alina Szapocznikow, Ryszard Stanisławski, Kroja mi się piękne sprawy. Listy 19481971. Kraków: Karakter.

Jałowik Delfina, Monika Kozioł i Maria Anna Potocka, red. 2016. Medycyna w sztuce, Kraków: Mocak.

Konrad Kuzyszyn. Autoportret zwielokrotniony. Dostęp: 12.12.2019.

Laurenza, Domenico. 2012. Art and Anatomy in Renaissance Italy. Images from a Scientific Revolution. New York: Metropolitan Museum of Art.

Leonardo da Vinci. b.d. „Traktat o malarstwie”. Tłum. Maria Rzepińska. W Myśliciele, kronikarze i artyści o sztuce od starożytności do 1500 roku, red. Jan Białostocki, 545-612. Warszawa: PWN.

de Liuzzi, Mondino. 1316. Anathomia Mundini. Pierwszy druk 1478, Padwa. Loukas, Marios, Alexis Lanteri, Julie Ferrauiola, R. Shane Tubbs, Goppi Maharaja, Mohammadali Mohajel Shoja, Abhishek Yadav i Vishnu Chellapilla Rao. 2010. Anatomy in ancient India: a focus on the Susruta Samhita. ,Journal of Anatomy” 217: 646-650.

Mandressi, Rafael. 2011. „Sekcje zwłok i anatomia”. Tłum. Tomasz Stróżyński. W Historia ciała. Tom I. Od renesansu do oświecenia, red. Georges Vigarello, 283-304. Gdańsk: słowo/obraz-terytoria. 
Millesi, Hanno. 2011. „Uwagi na temat akcjonizmu wiedeńskiego, jego poprzedników, następców i środowiska”. Tłum. Alexander Žigo. W Akcjonizm wiedeński. Przeciwny biegun społeczeństwa, red. Stanisław Ruksza, 130-161. Kraków: Mocak.

Müntz, Eugène. 2007. Michat Anioł 1475-1564. Tłum. Monika Czekanowska. Ożarów Mazowiecki: Firma Księgarska Jacek i Krzysztof Olesiejuk.

Morenz, Siegfried. 1972. Bóg i człowiek w starożytnym Egipcie. Tłum. Mieczysław Szczudłowski. Warszawa: Państwowy Instytut Wydawniczy.

National Library of Medicine. 2016. Historical Anatomies on the Web. Udostępniono 9 listopada 2019.

Nierzwicki, Krzysztof. 2013. „Andreasa Vesaliusa Traktat o budowie ciata ludzkiego - De Humani Corporis Fabrica”. Wiadomości Akademickie 49: 16-22.

Realdo Colombo, Matteo. 1559. De re anatomica libri XV. Wenecja: Nicolò Bevilacqua.

Reckit, Helena, red. 2012. Art and Feminism. London: Phaidon.

Reilly, Kara. 2014. „Two Venuses: Historicizing the anatomical female body”. Performance Research: A Journal of the Performing Arts, 19:4, 111-121. DOI: $10.1080 / 13528165.2014 .947129$.

Rispler-Chaim, Vardit. 1993. „The ethics of postmortem examinations in contemporary Islam”. Fournal of Medical Ethics 19(3) 164-168.

Simblet, Sarah. 2003. Anatomia dla artystów. Tłum. Monika Rolska. Warszawa: Arkady.

Sinelnikov, Rafail Davidovich. 1990. Atlas of Human Anatomy. Moscow: MIR Publisher.

Świtek, Gabriela. 2004. „Kadry z inkubatorów”. W Powinność i bunt. Akademia Sztuk Pięknych w Warszawie 1944 - 2004, red. Grzegorz Kowalski i Maryla Sitkowska, 348-355. Warszawa: ASP w Warszawie, Zachęta Narodowa Galeria Sztuki.

The Metropolitan Museum of Art. b.d. De humani corporis fabrica (Of the Structure of the Human Body). 1555. Dostęp: 09.11.2019.

Ważbiński, Zygmunt. 1972. Malarstwo quattrocenta. Warszawa: Wydawnictwa Artystyczne i Filmowe.

Wieczorkiewicz, Anna. 2000. Muzeum ludzkich ciat. Anatomia spojrzenia. Gdańsk: słowo/obraz terytoria.

2009. Monstruarium. Gdańsk: słowo/obraz terytoria. 
World Digital Library. 2016. Historia de la composicion del cuerpo Humano. Dostęp: 09.11.2019.

Vasari, Giorgio. 1985. „Leonardo da Vinci”. W Giorgio Vasari, Żywoty najsławniejszych malarzy, rzeźbiarzy $i$ architektów, tom IV, red. Karol Estreicher, 13-31. Warszawa-Kraków: PWN.

Voermann, Ilka. 2012. „The Artist of Witness: Otto Dix and Christian Schad”. W Otto Dix and the New Objectivity, red. Ilka Voermann, 36-47. Stuttgart: Künstmuseum Stuttgart we współpracy z Staaliche Akademie der Bildenden Künste, Hatje Cantz.

Zhaojiang, Guo. 1995. „Chinese Confucian culture and the medical ethical tradition”. Fournal of medical ethics 21: 239-246.

\section{Ilustracje}

il. 1. Andreas Vesalius, De humani corporis fabrica, 1543. The Metropolitan Museum of Art. Domena publiczna. Dostęp: 02.02.2020.

il. 2. Peter Paul Rubens, Studium anatomiczne stojq̨cego mężczyzny, 1616. Udostępniono 21 maja 2020. Domena publiczna.

il. 3. Jacques Gamelin, Nouveau recuil d'ostéologie et de myologie dessiné après charakter 1779. Gallica. Domena publiczna. Dostęp: 02.02.2020.

il. 4. Honoré Fragonard, Écorché konia i jego jeźdźca (fragment), 1766-1771, Museum Fragonard of the National Veterinarian High School of Alfort, Francja. Domena publiczna. Dostęp: 03.02.2020.

il. 5. William Bell, Major H. A. Barnum, Recovery after a Penetrating Gunshot Wound of the Abdomen with Perforation of the Left Ilium. W: Photographic Catalogue of the Surgical Section, 1865. Smithsonian American Art Museum and Renwick Gallery. Domena publiczna. Dostęp: 03.02.2020.

il. 6. Otto Dix, Neugeborenes Kind aufHänden (Ursus), 1927, (c) VG Bild-Kunst, Bonn 2020.

il. 7. Zoe Leonard, Wax Anatomical Model (Shot Crooked from Above), 1990, (C) Courtesy Zoe Leonard and Galerie Gisela Capitain, Cologne.

il. 8. Konrad Kuzyszyn, z cyklu Collegium Anatomicum 1, 1988-89, za zgodą artysty.

il. 9. Milja Laurila, Observatory, 2015, 7 UV prints on $4 \mathrm{~mm}$ acrylic glass, shelf $57 \times 190 \mathrm{~cm}$, Edition 5. Za zgodą artystki. 
il. 10. Milja Laurila, In Their Own Voice, 2016, 3 UV prints on $4 \mathrm{~mm}$ acrylic glass, shelf 60x130 cm, Edition 5, Photo: Marcus Schneider. Za zgodą artystki.

il. 11. Andres Serrano, Rat Poison Suicide (de la série «The Morgue »), 1992. Épreuve Cibachrome, 1/3 / Cibachrome print, 1/3, 125,7 x 152,3 cm / 125,7 x 152,3 cm. Collection Musée d'art contemporain de Montréal, (C) Andres Serrano. Photo: Richard-Max Tremblay. Za zgodą artysty.

il. 12. Andres Serrano, Fatal Meningitis, 1992, courtesy of the artist and Nathalie Obadia gallery. Za zgodą artysty. 


\title{
Abstract, keywords, about the author
}

\begin{abstract}
Anatomical Studies as a Subject and Challenge in Art. Historical Outline of Anatomical Illustrations and Contemporary References The cooperation of scientists and artists on projects focusing on human anatomy developed with the availability of deeper direct observations, e.g. during an autopsy. Over time, the demand for showing the body grew: the wider knowledge interested medics and artists, later also viewers unrelated to medical issues. The article presents the history of the development of anatomical studies in the context of illustrations and other objects visualizing human structure. Examples of contemporary references to the tradition of anatomical illustrations in art are also presented. The article presents works based on the characteristic features of atlas exemplification, but referring to social discourses and human condition.
\end{abstract}

Keywords: body, anatomical illustration, autopsy, contemporary art

Beata BIGAJ-ZwonEK, habilitated doctor, professor at the Jesuit University in Krakow. She graduated from the Graphic Arts Department of the Academy of Fine Arts in Krakow. Her scientific interests include knowledge about culture and art, in particular the issues of expression in art, the creative process, social and engaged art. Her creative work refers to nature of man, she presented her paintings at individual and collective exhibitions.

E-MAIL: beata.bigaj@ignatianum.edu.pl 